\title{
Bottomless Cup
}

Hannab McKinnon

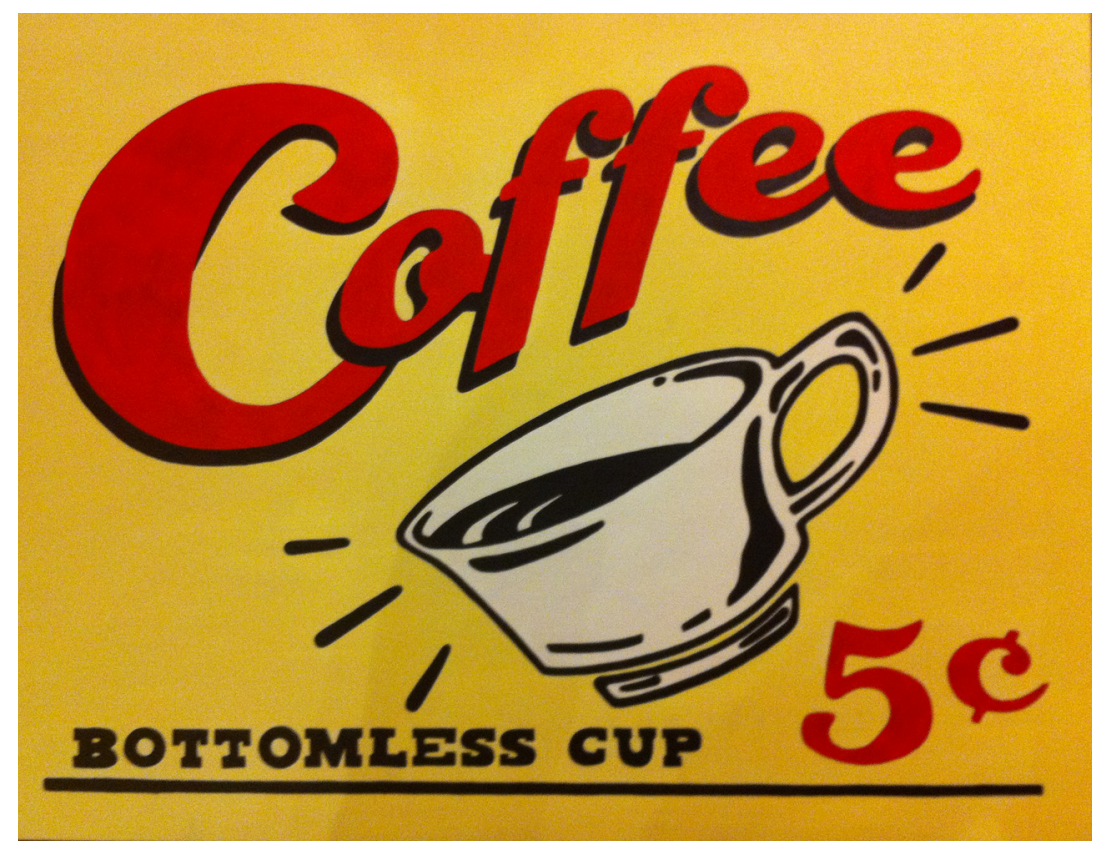

42 | Offset no. 11 